\title{
Bonnet, Spallanzani, and Voltaire on Regeneration of Heads in Snails: \\ a Continuation of the Spontaneous Generation Debate
}

By Marguerite Carozzi

Lazzaro Spallanzani's discovery of regeneration of heads in snails ${ }^{1}$ created a sensation similar to the one following Abraham Trembley's observation in the 1740 's of the extraordinary regeneration capabilities of hydra or freshwater polyps whose tiniest chopped up parts would grow into complete individuals. ${ }^{2}$ Since snails were easier to find than hydra, and the operation relatively simple, naturalists as well as laymen took to their scissors in order to find out whether an animal with eyes, a mouth, teeth, horns, and more important, a brain or a soul, could actually live after decapitation and then reproduce all its lost parts. The ensuing battle split naturalists from all over Europe into two camps: those who agreed with Spallanzani and those who disagreed. ${ }^{3}$ Voltaire was curious enough to try the experiments himself. In Les Colimaçons he wrote: "Il y a quelque temps qu'on ne parlait que des Jésuites, \& à présent on ne s'entretient que des escargots.» (Not long ago everybody talked only about Jesuits, at present snails are the talk of the town). ${ }^{4}$ This paper will analyze and compare the experiments and conclusions by Spallanzani, Charles Bonnet, and Voltaire to show that while the two naturalists tried to prove the existence of preexisting germs in regenerating animals, and thus continued their fight against the theory of spontaneous generation and epigenesis, Voltaire wrote a satire to make fun of the whole debate and warn naturalists of charlatans.

The snail controversy represented, in fact, merely a continuation of the spontaneous generation controversy, but it has not been studied as such whereas the latter has received much attention. ${ }^{5}$ After Trembley's discovery, the prevailing theory of preexistence (or preformation) came under attack. ${ }^{6}$ According to Farley, the theory of preformation teaches that "development is the mere mechanical growth of a miniature preformed in parent organism" whereas the theory of preexistence helds that the "germ of preformed parts is not produced by the parent, rather it is created by God at the beginning and is conserved in that state until the moment of its development or l'évolution." " I shall use the term preexistence since Bonnet and Spallanzani believed in development of preexisting germs before 
fertilization, and hence not in a new creation, and Voltaire in his satire of a physician from St. Flour expressed the belief that God had made the snails, the sun, and the stars. Epigenesists held that some physico-chemical forces were at work. Pierre Louis Moreau de Maupertuis suggested forces which resembled attraction in cristallography («arbre de Diane»), John Turberville Needham believed in a vegetative force, and Georges Louis Leclerc de Buffon speculated that organic molecules were assembled in some «moule intérieur» which he attributed to gravitational forces. ${ }^{8}$ Together, Needham and Buffon are said to have reestablished the theory of spontaneous generation in the eighteenth century. ${ }^{9}$

I have chosen the snail controversy in the belief that the motives or reasons which influenced Spallanzani, Bonnet, and Voltaire appear magnified and clearer in the snail controversy than in the many versions included in the complete works of the three authors. Indeed, Spallanzani and Bonnet were forced to test their theory of generation. Since they believed that generation and regeneration were identical, that is development of an organic whole or part of a whole before fertilization, ${ }^{10}$ the theory of preexistence not only applied to their experiments on generation, in particular Spallanzani's opposition to Needham and Buffon, but also to experiments on regenerating animals. If they believed in the theory of preexistence, preexisting germs alone could cause new heads in snails. And these germs needed to be seen and described. Voltaire, in turn, had to take a stand on what he saw in regeneration and what he believed about the larger controversy on generation.

\section{Bonnet's and Spallanzani's search for preexisting germs}

Before Spallanzani's discovery of regeneration in snails, Bonnet, in the absence of hydra in the neighborhood of Geneva, had dissected earth-worms in order to test Trembley's discovery. He found that some lower animals had indeed the capacity to regrow lost parts. In his treatise on insects (1745), he refrained from formulating any theory on generation although he showed himself strongly in favor of preexistence. He wondered how, during decapitation, the animal soul could survive, adding the famous phrase, to be repeated by Voltaire in his satire: «Apprenons à admirer et à nous taire.» (Let us learn to admire and to remain silent.) ${ }^{11}$ 
Bonnet was, however, not a man to remain silent. Since he was no longer able to refute epigenesists in the laboratory because of serious eye problems, he became spokesman of naturalists who published influential works in favor of the theory of preexistence. After Albrecht von Haller's observations on chicken embryos, Bonnet declared that he had waited for such a proof of preexistence all along. In Considérations sur les corps organisés (1762) he said: "It was necessary to prove that the preexisting germ belonged to the female before fecundation ... Finally, this important discovery for which I had waited, and which I had dared to predict, was announced to me in 1757 by the 'Baron de Haller'." In 1765, he was more than happy to become mentor to the promising Italian naturalist, Spallanzani, who had independently disproved Needham and Buffon in his Saggio di osservazione microscopiche..${ }^{12}$, published that same year.

Although Bonnet seemed convinced that generation could only be explained by preexisting germs and not by any physico-chemical or other forces proposed by epigenesists, he still favored two sources of regeneration: a new skin may develop from «filaments gélatineux» during some accidental derivation of nourishing fluids whereas an organic whole must have been preformed and enclosed in a "button". ${ }^{13}$ When he was asked to lead Spallanzani's research on animal reproductions, Bonnet first wanted to find out which of the two postulates made in Considerations applied to regeneration. Thus he wrote to Spallanzani:

We must above all find out whether these parts of salamanders exist originally in a minute germ or whether they are mere prolongations of some animal fibers ... We shall not accept that some molecules clustered by accident and produced a tail or any other part. This way of thinking would be the end of physics. ${ }^{14}$

Spallanzani accepted his master's intentions:

My first aim has been to discover whether mere prolongation of ancient fibers suffices to explain the various phenomena, or whether it is necessary to accept preexisting germs which developed. I have seen for myself, and firstly in earth- and freshwater-worms, that mere prolongation cannot explain experiments and that one has therefore to resort to development of preexisting germs. ${ }^{15}$

Because of the head, the eyes, the mouth, the teeth, and the brain in snails, regeneration of these parts presented greater difficulties for the theory of preexistence than in other regenerating animals. Indeed, in a letter written before the publication of Spallanzani's Prodromo, Bonnet admitted that he had not anticipated that a snail could actually reproduce a new head. He was 
puzzled about the eyes as being real organs and suggested that these black points in the larger horns might be optical nerves or "papillas." 16 Even more perplexed about the many irregularities in regenerating snails, as reported by Spallanzani, he objected: "... it is not the same as in earth-worms where a small button actually encloses an organic whole; in snails different parts of the head appear in succession without any order. Sometimes the mouth, the lips, the horns, and sometimes all these parts together at once." These phenomena certainly did not agree with the theory of «emboitement.» Bonnet, however, had been in such a spot before when he had to explain regeneration in hydra. There, he had admitted that new parts are not enclosed in a germ but that they are caused by a secret preorganization or dissemination of germs. In his letters to Spallanzani, he thus showed faith in some future system of laws which would explain the occurrence of regeneration under particular circumstances. ${ }^{17}$

Bonnet was aware that other theories besides preexistence might be able to explain regeneration. He told Spallanzani: "Never lose track of the infinite number of means by which the «Sagesse Suprêmes has arrived at the same end. Germs are only one of these means, but they are not all the means." 18 As his knowledge of difficulties grew, he described germs as many different things. Sometimes he used the term «emboîtement», elsewhere he opted for a diffusion of germs in the whole body, or for a growth of «filaments gélatineux» or even a secret preorganization in hydra. ${ }^{19}$ When he first began to collaborate with Spallanzani, he was undecided about the form or place of preexisting germs. He was even open to several interpretations as long as God was present in the background while matter arranged itself by different combinations. He was, in fact, very close to the beliefs of epigenesists. In the snail controversy, however, Bonnet had to narrow down his wide acceptance of different kinds of germs. This led him to speculate on things he had not seen. To this we shall come in a moment.

Spallanzani's Prodromo did not point out the existence of germs in regenerating animals. Only in the preface did he mention the theory of preexistence in relation to his discovery of miniature tadpoles in frog eggs before fertilization. Spallanzani believed that this fact confirmed Haller's experiments on chicken embryos so that "both discoveries ought to end the controversy which for so long has divided philosophers on the origin of germs." ${ }^{20}$ Although he had started his investigation in animal reproduction to prove that preexisting germs exist somewhere in these animals, as much as miniature tadpoles exist in frog eggs before fertilization, his observations 
remained entirely on the descriptive level. He was intrigued by many aspects and wondered whether blood vessels in the reproducing tail of tadpoles had existed in a rudimentary stage, invisible to the naked eye and even under the microscope, or whether they were formed in successive stages. ${ }^{21} \mathrm{He}$ believed that membraneous skin and some new fibers on a tail of a tadpole were merely prolongations of old parts. ${ }^{22}$ He asked why an organic whole popped out from the trunk in earth-worms whereas in a decapitated snail new parts appeared almost randomly, and sometimes they were monstrosities. Were these monstrous reproductions errors or sports of nature or were they caused by certain constant and invariable laws of nature? ${ }^{23}$ Although Spallanzani probably repeated some of Bonnet's questions in his Prodromo, he did not try to theorize on these laws. He told Bonnet that the most important task for him was to look at facts, to analyze and compare them, and that although he preferred preexistence to epigenesis he did not want his reader to perceive his preference. He wanted his reader to judge him by the facts and the immediate consequences drawn from these facts. ${ }^{24}$

The discovery of regeneration in snails was discussed heatedly in the Avant-Coureur starting in May 1768. The French naturalists Michel Adanson and Valmont de Bomare as well as the abbés Cotte and Wartel were opposed to Spallanzani's discovery. Andanson claimed rather humorously in his letters to Bonnet that only the «bonnet» or cap had been cut off, that is merely a piece of skin or flesh, but that no vital organs had been touched..$^{25}$ Among those who confirmed Spallanzani's experiments were the French Antoine-Laurent Lavoisier, the German J. Th. Schaeffer, the famous Signora Bassi, aunt of Spallanzani and professor of physics at Bologna, and friend of Voltaire. The debate in the Avant-Coureur did not seem to split epigenesists from believers in preexistence, nor French from Italian or Swiss naturalists, nor Christians from atheists. Most of Spallanzani's opponents seemed unable to conceive that such a highly organized animal as the snail could reproduce its head. As far as I know, only Bonnet and Spallanzani were searching for preexisting germs.

\section{Bonnet's and Spallanzani's final stand on preexistence}

When Spallanzani gave no signs of publishing his promised work on animal reproductions, although Bonnet kept asking him to, ${ }^{26}$ the latter decided to experiment himself. He hired a draftsman who was also a good observer and 


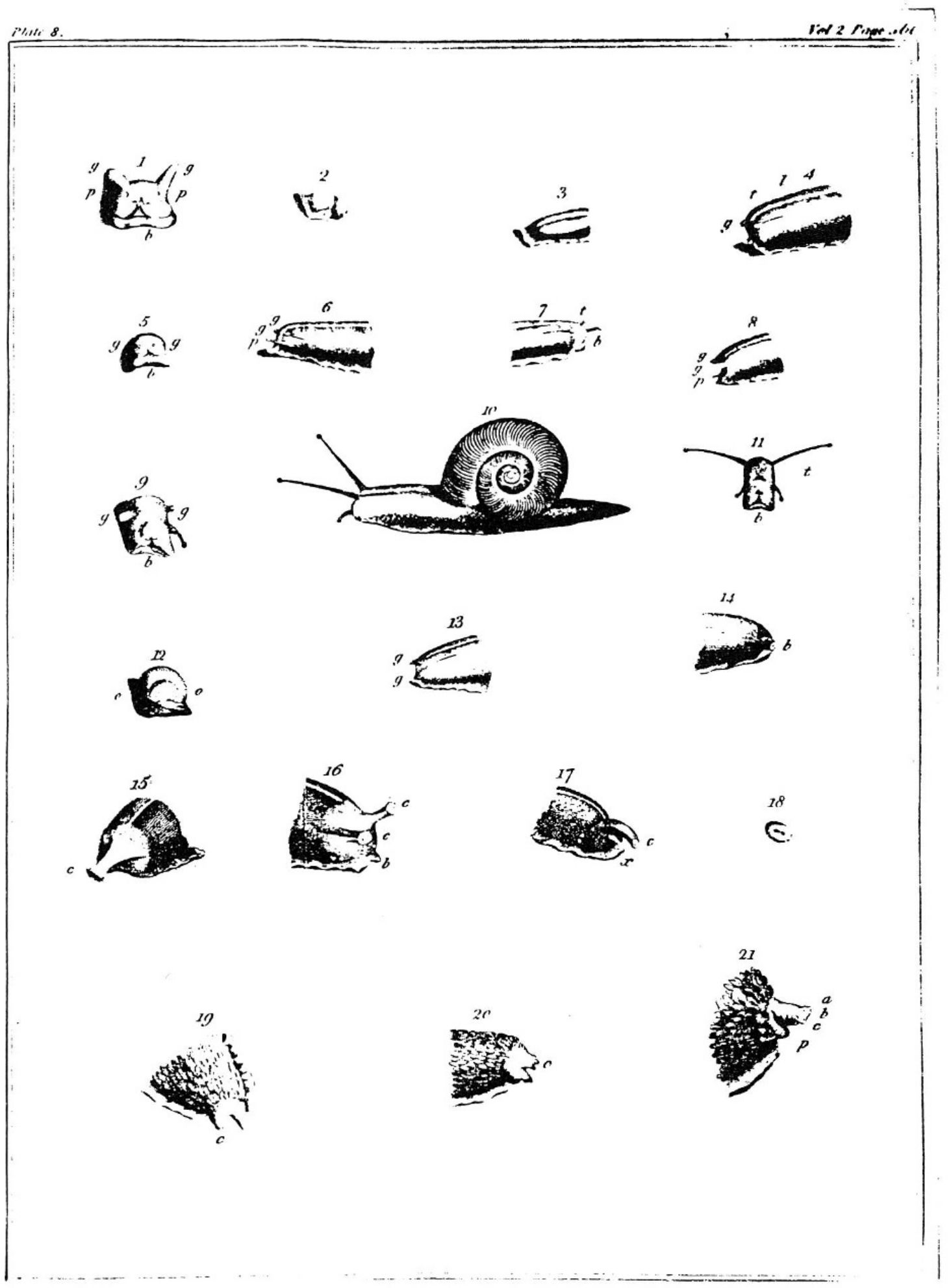

Figure 1. Reproduction of drawings by Charles Bonnet, originally published in Observations sur la Physique, sur l'Histoire Naturelle et sur les Arts, vol. 10, Paris, 1777, in Tracts on the Natural History of Animals and Vegetables, 2nd, ed., vol. II, Edinburgh, 1803, plate 8, p. 360 
together they dissected a great number of snails and newts (Fig. 1). In his first memoir on snails Bonnet claimed: "The only object of publishing my experiments on the reproduction of the head of snails is to afford an additional confirmation to the Abbé Spallanzani's beautiful discovery." 27 We shall see, however, that in his memoirs on newts, Bonnet's main goal was to defend the theory of preexistence inferring that newts and snails undergo similar processes of regeneration.

Bonnet encountered so many irregularities and deformities in regenerating snails, while more than two-third perished, that he abondoned these animals in order to experiment on newts instead where regeneration is constant and always forthcoming. In his first memoir on newts (1777), Bonnet reached the tentative conclusion that it was very probable that an organic whole of a new leg preexisted in miniature form in germs. ${ }^{28}$ In his second memoir written in 1779 , he stated with more conviction that he wanted to prove that reproducing limbs in newts contained the same sources of regeneration as exist in cut limbs, namely preexisting germs. ${ }^{29}$ For that purpose he cut one arm and one leg of two different newts who had just reproduced these members for the first time. Then he cut them again and again and thus examined four successive regenerations of arms and legs with more or less the same number of fingers and toes. This constancy led him to consider preexistence of germs which were destined to repair lost members as a physiological truth in nature. ${ }^{30}$

Bonnet seemed now able to refute the epigenesists. With footnotes to the works by Maupertuis, Needham, Wolff, and Buffon, he said that "powers of relation," "vegetative, expansive, or essential forces," as well as «moules intérieurs» and "organic molecules," were mere words which did not explain anything:

How could the imaginary vegetative power determine the production of a leg rather than an arm, which it might just as readily produce? How could it give each part of the leg that figure, proportion, and structure, which constitute the member? ... To affirm that a certain expansive force, residing in the trunk of the old members, extends the vessels, nerves, muscles, and bones, is saying nothing at all: for it is evident, that only a simple stump or fleshy cone would result from such an elongation. But could the cone have a hand or a foot at the extremity provided with fingers and toes? Could all their articulations be present, and could the same order and proportion prevail? ${ }^{31}$

Bonnet's strong arguments against epigenesists were, however, not matched by proofs of preexisting germs in newts or snails. He simply said that since he did not know of any better explanation, "I admit that in the interior of the 
members of the newt, there are germs destined to repair lost parts." The closest he came to "see" these hypothetical germs were his words, "a conical 'mamelon' in its origin was the germ." Nevertheless, he speculated that in newts, snails, and earth-worms, experiments "seem to indicate that the original and primitive figure of germs is spherical or eliptical," and that limbs of regenerated animals undergo processes similar to developing chicken embryos. ${ }^{32}$

When Bonnet compared regeneration of legs and arms in newts with regeneration in snails, he avoided the fact that newts do not regenerate heads as snails do. Indeed, he was forced not to mention the entire head of the snail but only the horns. Thus he wrote in his memoirs on newts: "How would a simple prolongation of fleshy fibers at the base of a cut horn of a snail be able to produce a new horn and how would it [prolongation] place at the extremity of this horn an eye provided with the uvea and three humors"? Here Bonnet compared regenerating tails of newts merely with regenerating horns in snails but not with their heads. ${ }^{33}$ When he published his Euvres two years later, he went even further to confirm a non-existing conformity between newts and snails, adding in a footnote to the above memoir: "What I observe with respect to the reproduction of newts should also apply to those of snails. We have only to reflect on all I said about their regenerated horns, and eyes, and remember the admirable organization of these parts." " It appears, therefore, that Bonnet wrote his memoirs on snails and newts in an effort to defend the theory of preexistence. Instead of visible proof of preexisting germs, he could, however, only present speculations.

Spallanzani did not speculate. Instead of the promised work on animal reproduction, he published only two memoirs on regeneration of heads in snails in 1782 and $1784^{35}$ (Fig. 2). In these memoirs, he added very little to what he had said earlier. He merely wanted to defend his position as the discoverer of regeneration in snail heads. He had not completely given up the idea of germs in sea-stars and tadpoles. In the rays of the sea-star when cut off, he observed a little cone or tongue protruding from the middle of the trunk which he called "the expanding germ of the defective portion." ${ }^{36}$ In tadpoles, he mentioned a "minute limb, yet a germ" which was going to perforate the trunk. In adult frogs, indurated fibers, a "cicatrice", would "prevent the reproducing germ from breaking through and expand." 37 Nevertheless, he did not point to any analogy between regenerating newts and snails. On the contrary, he said: "newts never defraud the eager experimentalist of its multiplied reproductions, which is otherwise in snails, 


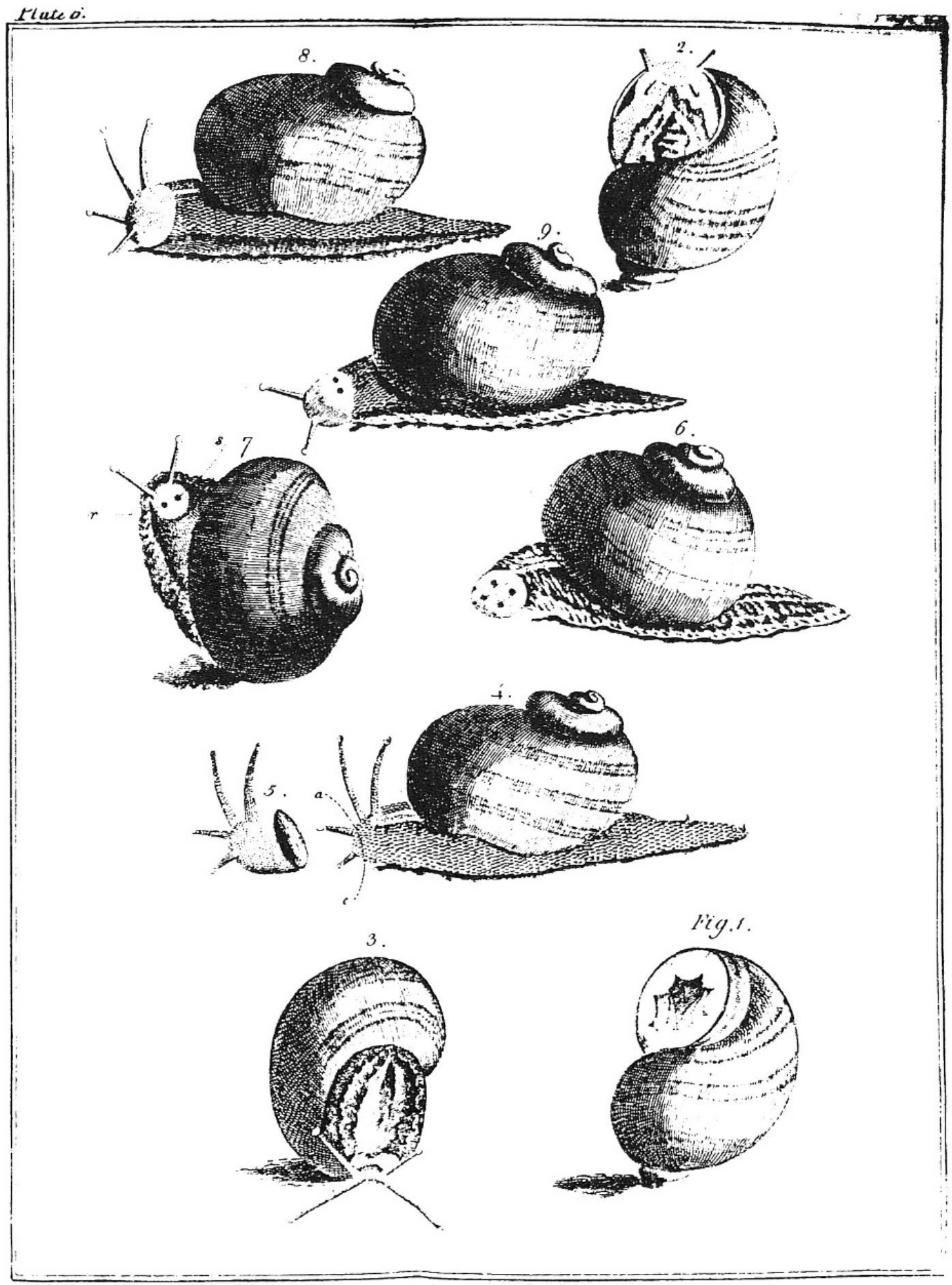

Figure 2. Reproduction of drawings by Lazzaro Spallanzani, originally published in Memorie di Matematica e Fisica della Società Italiana, Tome I, Verona, 1782, p. 612, in Tracts on the Natural History of Animals and Vegetables, 2nd, ed., vol. II, Edinburgh, 1803, plate 6, p. 250 
as some of them will not reproduce." He also mentioned again that reproduced parts in snails were not always perfect and that no organic whole, including all the parts of the severed head appeared on the trunk of the decapitated snail, but that these parts were separated and developed in succession while some parts never reproduced or showed monstrosities. ${ }^{38}$

Monstrosity in generation was one of the greatest stumbling blocks in the theory of preexistence. «Combien a-t-on peine à digérer que des germes difformes ou monstrueux soient sortis immédiatement des mains du créateur!» (How difficult it is for us to accept the fact that misformed or monstrous germs should have originated in the hands of the Creator) said Bonnet in a letter to Spallanzani. ${ }^{39}$ In the same letter he admitted that he did not know how to explain monstrosities in heads of snails. Could they have originated from monstrous germs or was the animal's health or perhaps the place where the instrument had cut the head responsible for monstrosities? Spallanzani repeated similar uncertainties in his memoirs of $1782 .{ }^{40}$

Why did regeneration occur in other animals? Spallanzani said that it was not simplicity of organization, since newts were much more complicated than polyps, nor was tenderness or delicacy of fibers the main condition, since animals more delicate than hydras perished when cut in pieces. However, animals with tender fibers had better chances to regenerate than others; for instance, tadpoles grew new limbs while frogs did not. ${ }^{41} \mathrm{He}$ concluded that a certain temperature was required for regeneration to occur:

Reproduction is finally nothing more than a new generation with this single distinction, that in ordinary generation an organic whole originated and unfolded, while in reproduction only part of that whole is developed. The same conditions requisite for the origin of the whole are required for the origin of a part, and among these conditions are heat. ${ }^{42}$

It seems possible that Spallanzani abandoned his work on animal reproduction because he had not found any preexisting germs. Thus he reduced a work on regeneration in worms, newts, salamanders, and tadpoles to two memoirs on his dicovery of regeneration of snail heads where his reputation as discoverer was at stake. It could well be that since experiments on regenerating animals remained inconclusive and in no way contributed to the larger issue of generation, these experiments also marked the end of the spontaneous generation debate. Indeed, after 1784 Spallanzani turned to geological travels and other interests where preexisting germs were not the issue whereas in Germany, Johann F. Blumenbach had observed in 1781 that "not a trace, not a shadow ... of a preformed germ" was visible in the 
transparent regenerating polyp. Bodemer mentions that the concept of regeneration as creation and not just development of preexisting germs destroyed the theory of preexistence. ${ }^{43}$ The first decades of the nineteenth century witnessed a return to the theory of spontaneous generation and epigenesis. ${ }^{44}$

\section{Voltaire's Les Colimaçons}

Two French biologists have given Voltaire credit as an amateur naturalist during the snail controversy. Edmond Bordage claimed that Voltaire should be given priority in the discovery of regeneration in snails because he had not only made the operation first, but he also knew exactly where to cut the head in order not to injure the brain. Spallanzani and others had incorrectly believed that they had removed the brain whereas what we call today «ganglions cérébroïds» had simply moved backward during the complete extension of the snail and had thus remained untouched. ${ }^{45}$ Marcel Abeloos stated in 1942 that neither the brain nor any other internal organs were responsible for regeneration in snails; regenerative capacities depended upon some zones which influenced certain tissues. ${ }^{46}$ Jean Rostand corrected Bordage's judgment of Voltaire in 1951 stating that, firstly, Voltaire had merely repeated Spallanzani's experiments mentioned in the Avant-Coureur of May 20, 1768; secondly, Voltaire had accepted objections, probably made by Adanson, in regard to regeneration of the brain. Rostand, nevertheless, believed that Voltaire had been seriously interested in the phenomenon and had done some experiments himself. ${ }^{47}$

A comparison of Voltaire's Les Colimaçons (Fig. 3) with his more serious work, Les Singularités de la nature, both in the original version, raises some initial doubts about Rostand's last statement. ${ }^{48}$ There is much carelesness as to the number of snails, their time of regeneration, and their species. In Les Colimaçons twenty slugs and twenty snails are mentioned, but in Les Singularités de la nature only fifteen of the former and an undertermined number of the latter. The time of reproducing new heads varies from two to six weeks in the two works. According to Voltaire, slugs, that is «limaces incoques», reproduced heads much better than snails, that is «limaçons à coquille». In a footnote of Les Colimaçons (p.4) he referred to a translation of the Italien Prodromo which had said exactly the contrary. In his letters to M. d'Argental (27 July 1768), Mme du Deffant (30 July 1768), and M. de Chabanon (2 November 1768); in his articles "Polypes" and "Serpent" in 


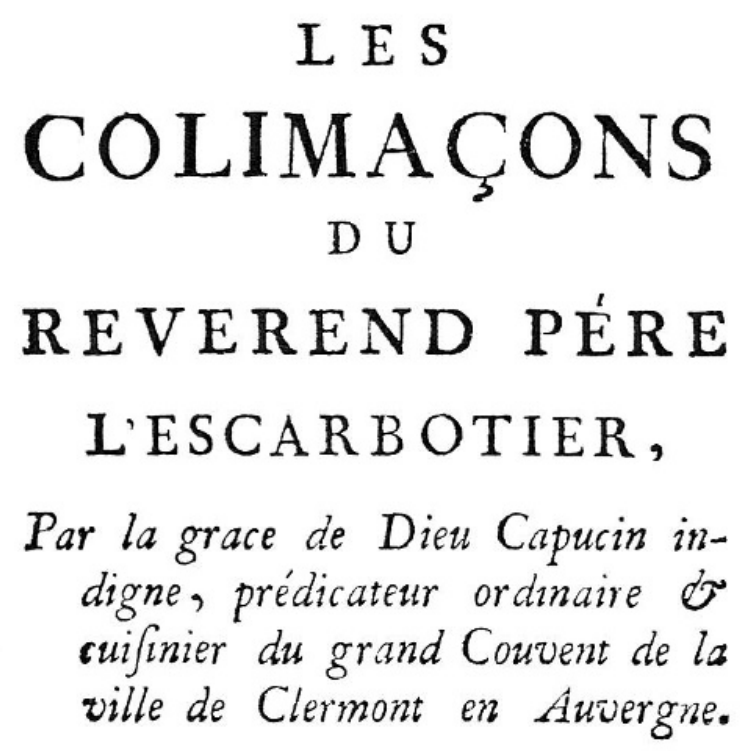

A U

Reverend Pére Elie, Carme chauflé,

Docteur en Théologie.

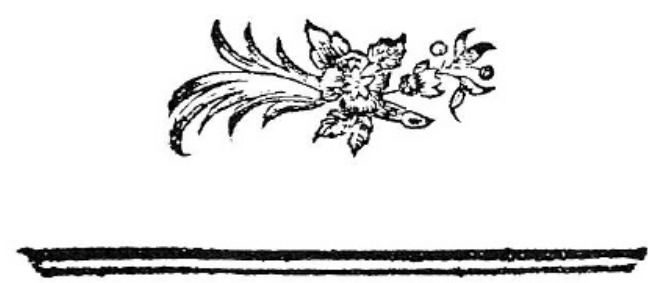

1768 .

Figure 3. Title page of the original 1768 edition of Les Colimaçons at the Institut et Musée Voltaire, Geneva, with permission 
Dictionnaire Philosophique; in his Rétraction ... (1771), and finally in his letters to Spallanzani in 1776, Voltaire switched to «colimaçons» or «limaçons» having probably become convinced of his error. ${ }^{49}$ Nevertheless, in Les Colimaçons Voltaire insisted that the controversy concerned the issue whether slugs or snails regenerated new heads while it was, on the contrary, whether snails reproduced heads or not. All this raises the question whether Voltaire had, in fact, decapitated any snails. The operation was after all not so simple because the animal immediately retracts its head so that it is most difficult to know where is what. However, Voltaire's description of the snail's eyes is vivid and careful:

This is what I saw. There is a black grain at the extremity of the great upper antennas. When touched, this black point descends into the cavity of these two horns through some kind of vitreous humour and afterwards it rises swiftly; but these two black points seem to be lacking in the lower horns or antennas which are smaller. The two larger antennas are the eyes, the smaller ones seem to be horns with which the snail and the slug look for food. (p. 8)

Furthermore, his letters to Spallanzani repeat his experiments so that we must believe that Voltaire himself was at work.

Voltaire probably chose a careless style in Les Colimaçons on purpose. He used similar tactics in his Saggio intorno ai canbiamenti su'l Globo della Terra (sic) published in Paris in 1746, in La Défense de mon oncle (1767), in L'Homme aux quarante écus (1768), in Les Singularités de la nature (1768) where he took part in the controversy on fossils, on mountain-building, and spontaneous generation. ${ }^{50} \mathrm{He}$ had at least two reasons to do so. First, to protect himself from naturalists by giving the impression that he was merely a meddling amateur and joker and no longer on the forefront of any field of science as he had tried to be at Cirey, and second, to retaliate against some naturalist or naturalists. Thus he began Les Colimaçons by laughing at experimental practices which require the exact recording of time, the place, the tools, the temperature, and so forth: "On the twenty-seventh of May, at nine o'clock in the morning, the weather was fair, I cut the entire head with its four horns of twenty naked slugs without shells of a "mort-doré» color ..." (p.5). In short, Voltaire had no desire to be made a laughingstock among the scientific community, he much preferred to appear ignorant and make jokes about naturalists.

For the purpose of disguising tactics, Voltaire used four characters, namely the Reverend Père l'Escarbotier who decapitated slugs and snails; the Reverend Père Elie, doctor of theology, who provided explanations 
according to the Bible; a physician from St. Flour who wrote a dissertation, not only about snails, but also on other controversial issues, and the editor of Les Colimaçons.

The Reverend Père l'Escarbotier, apparently naive but good at cooking «les fricassées d'escargots aux fines herbes», did the experiments and wrote letters to the theologian Père Elie. He mentioned the results and referred to various reactions among his colleagues. One argued in Cartesian terms and said that since the soul resided in the pineal gland, it must have left the body when the animal was beheaded and could not return to a new head. Another colleague wondered whether the soul could remain in a body without head and whether there existed germs in that body who could produce four horns, eyes, a throat, teeth, a snout, and thoughts (p.9-10).

The Reverend Père Elie had a simple answer to the question. According to various passages in the Bible, a soul exists in all parts of the body. In animals ("brutes"), it resides in the blood; but since snails have no blood, they harbor the soul in their horns. Upon decapitation, the soul flees to the animal's behind where it stays until the head is reproduced. "Nothing is more natural and more appropriate." (p.11-12). Thus was the center of intelligence, the soul, and its residence explained by Voltaire's theologian.

The same theologian, however, did not like the dissertation on spontaneous generation by a certain physician from St.Flour. He warned l'Escarbotier: "Be careful, my dear Father; do not become seduced by dangerous philosophers who claim that all animals and plants are born from developing germs and that nothing comes from corruption. This is heresy"! Indeed, according to Saint Thomas, generation originates from corruption, and Saint Paul, in his address to the Corinthians, said that seeds cannot grow in the soil if they do not perish first. Even Saint John preached that a grain of wheat remains barren if it does not die in the soil (p.22-23). Satirizing passages in the Bible which confirm spontaneous generation, Voltaire thus ridiculed both the Bible and naturalists who believed in spontaneous generation.

In the dissertation by the physician from St. Flour, Voltaire might have given his own view on regeneration and generation. He made a distinction between regeneration in snails which is a mystery that nobody has been able to explain and generation which he described according to the prevailing theory of preexistence, or in the words of the physician: "All I know for sure is the fact that generation of snails is as old as the world, that like begets like and that nothing comes from nothing ever since something exists." At the 
end of the dissertation, he wondered whether animals have sensations and ideas and if they do, who gave these sensations to animals? "It is he who made the snails, the sun, and the stars because animals cannot give sensations to themselves." (p.21) Since Voltaire made similar statements elsewhere, in particular in his comments on Bonnet's Considérations sur les Corps organisés in 1764, we must assume that he believed in the prevailing theory of preexistence. ${ }^{51}$ In that work Voltaire shows himself to be wellacquainted with all the problems concerning generation; Jacques Marx says that we cannot deny that Voltaire made inquiries and that his scientific baggage was sufficident to comment on Bonnet's work with clear understanding. ${ }^{52}$ While Voltaire accepted the concept of divine creation, he refused any further speculations such as proposed by Bonnet in his latest work La Palingénésie. There Bonnet stated that God had not only created all living things but that he also provided for preexisting germs of species to gradually attain higher levels of organization, so that men will become angels, apes will become men, and all will gradually move up the Great Chain of Beings. ${ }^{53}$ Voltaire also ridiculed the concept of the Great Chain of Beings stating that there exists no visible gradation between animals: "We see animals with four and two legs, but none have three ..." ${ }^{54}$ In short, Voltaire did not care for speculations in the field of the life sciences.

The dissertation by the physician of St.Flour contains refutations of system-makers very similar to those made in Voltaire's other works written in 1767 and 1768 mentioned above, hence the physician of St.Flour is probably Voltaire's closest voice. Why then are there relatively little jokes on behalf of Needham's eels? Recent studies have shown that after the publication of Spallanzani's Saggio in 1765, Needham was considered "the obvious loser" by Bonnet, Trembley, and Haller in Switzerland, or that Needham was at least "initially daunted." 55 This explains why Voltaire felt no need to discuss the spontaneous generation any further except to mention that Needham's system had been successfully refuted by Spallanzani. Voltaire merely mentions Needham in relation to a "geometer, a man who has rendered great services in physics," [Buffon] but who was seduced by Needham's system (p. 14-16). Indeed, Buffon and not Needham was the target in Les Colimaçons. He is referred to as "the same physician who despite his 〈lumières〉 had accepted Needham's eels, later also adopted Maillet's mountains." Voltaire then criticized theories of mountainbuilding by the sea with citations from Buffon's Histoire naturelle (p. 16-18). It appears that Voltaire considered the spontaneous generation debate 
closed and wished to refute Buffon's i.e. Maillet's system on mountainbuilding.

My studies on Voltaire's attitude toward geology have revealed that all the works written in 1767 and 1768 mentioned above, starting with $\mathbf{L a}$ défense de mon oncle, contain direct and indirect critics of Buffon, the author of Histoire naturelle who had slandered him in that work in 1749 . When Buffon's Complete Works were sent to Voltaire in 1767 by Panckoucke, old wounds reopended and prompted him to retaliate. In La défense de mon oncle he defended himself saying, "I keep an attitude of respect (charité) toward all 'doctes' until they slander me or attack me otherwise. Man is made in such a fashion that he dislikes to be slandered or vexed." ${ }^{56}$ A large part of the dissertation by the physician from St. Flour seems, therefore, to be directed toward Buffon.

A fourth persona, the editor, ends with the following words which according to Rostand are "Voltaire"s real conclusion": ${ }^{57}$

It is a fact that slugs reproduce new heads after two or three weeks and that snails do likewise when their heads are cut between the four horns. Every little boy can do this experiment, but is there a man who can explain it? Philosophers, and theologians, unfortunately, reason as little boys do. Who can explain how a soul, a principle of sensations and ideas can reside between four horns, and how the soul remains in the animal when the four horns and the head are cut?... This astonishing fact is part of the instrinsic works of nature, of its first laws which we cannot understand any better than the nature of the inhabitants of Sirius and Canope. As soon as we start digging we find an infinite abyss. We must admire and remain silent. (p.23)

The first part of the above conclusion agrees with Spallanzani's empirical approach and with the words "il faut admirer et se taire," Bonnet's methaphysical statement made in 1745 is repeated. We do not know, however, whether Voltaire spoke through the editor, the physician, or both.

In Rétraction nécessaire des auteurs des questions sur l'Encyclopédie, Voltaire recanted what he had said in Les Colimaçons on regeneration in snails:

My first retraction concerns the scissors which I have used to cut several heads of snails. All the heads regenerated in 1772; but those which I cut in 1773 did never return. Persons of greater skill than myself told me that when my heads came back to life, I had merely cut the skin of their face but had not touched their brain which is the source of life as in humans. When I cut the entire head with more expertness, it did not reproduce. ${ }^{58}$

Before his correspondence with Spallanzani, Voltaire thus accepted objections made by Adanson and Valmont de Bomare. The latter wrote in his 
Dictionnaire raisonné universel d'histoire naturelle that he had cut the head of fifty-two snails, and that all snails which had been skillfully cut died within a few days while those which retracted too fast survived with mutilated horns. ${ }^{59}$

In 1776 Voltaire asked the Italian naturalist what he thought about his experiments on snails (May 20, 1776). Spallanzani reassured him that he, Voltaire, had indeed cut real heads and not only «visaggi» (faces) (May 31, 1776) whereupon Voltaire answered:

Your letter of May 31 revives my past hopes. I had relinquished the honor of restoring heads to snail. I had the modesty to believe that I was not at all suited to make miracles. However, I remember very well to have seen new heads return to snails which I had decapitated. But good naturalists had brought down my vanity ... But since you assure me that you have cut real heads and that they returned, my confidence is restored and I begin to think that nature is capable of everything. ${ }^{60}$

This letter implies that Voltaire felt insecure among naturalists and all too inclined to doubt his own experiments and judgments. He had reacted likewise in his attitude toward fossils. When the famous Jean-Etienne Guettard told him at Ferney that fossil shells in the neighborhood were of marine origine, he doubted his own observations and correct interpretation of freshwater fossils in the Chattian freshwater molasse at Ferney. ${ }^{61}$ Voltaire's attitude toward naturalists was indeed a strange mixture of insecurity, modesty, and fear of charlatans who had the arrogance to sell new ideas which according to Voltaire were not sustained by facts. This is why, I believe, that Voltaire's statements on natural history are most always couched in ambiguous terms so that his contemporaries, such as Buffon, could not attack him. At the same time he was free to warn naturalists of charlatans. According to his Dictionnaire Philosophique, Voltaire considered a charlatan any man who was trying to sell his ideas. He would build a system in physics, metaphysics, or scholastic theology and sell it to an audience. Courtiers would applaud, idiots would believe, and protectors would give support. Many of his works written in 1767 and 1768 contain such statements:

The study of nature is not a satire. Let us be aware of appearances which are so often deceitful; of masterful authority that always tries to win, of charlatanism which so often accompanies and corrupts sciences; of the gullible crowd which for some time is the echo of a single man. ${ }^{62}$ 


\section{E S \\ COLIMACONS \\ D U \\ REVEREND PÉRE \\ L'ESCARBOTIER, \\ Par la grate de Dieu Capucin in- digne, prédicateur ordinaire or cuifsnier du grand Couvent de la ville de Clermont en Auvergne.}

A U

Reverend Pére Elie, Carme chauffé,

Docteur en Théologie.

NOUVELLE EDITION.

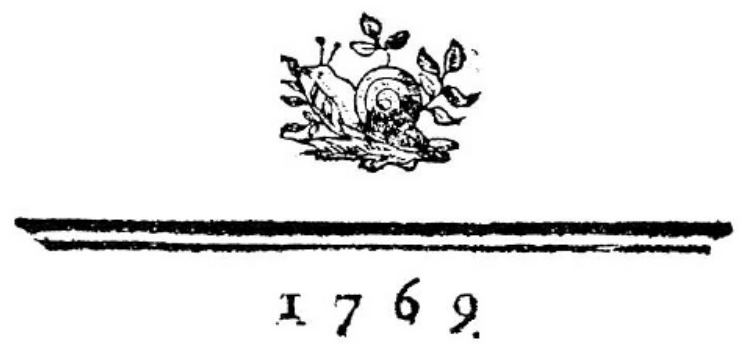

Figure 4. Title page of the original 1769 edition of Les Colimaçons at the Institut et Musée Voltaire, Geneva, with permission 


\section{Conclusion}

This study has shown that the debate about regeneration of snail heads represented, in fact, a continuation of a larger controversy on spontaneous generation and epigenesis. Bonnet and Spallanzani were both engaged in a search for preexisting germs in regenerating animals in order to provide visible proof to refute the theory of epigenesis. While Bonnet refuted epigenesists and claimed unfoundedly that preexisting germs occurred in snails as well as in newts, Spallanzani would not let the theory of preexistence dictate his description of his observations. It seems possible that his inconclusive experiments on regeneration made him abandon this area of study and that the debate on spontaneous generation and preexistence versus epigenesis had thus come to an end.

While the motives and reasons which influenced Spallanzani and Bonnet are clearly noticeable in their works on snails and the related correspondence, such is not the case with Voltaire's Les Colimaçons (Fig.4) because he wrote a satire with four different points of view. What he really thought about the origin of life and spontaneous generation is certainly not made clear in that work. We can only guess that the physician from St. Flour and the editor are probably Voltaire's spokesmen since he showed himself in favor of the prevailing theory of preexistence in other works, in particular in his comments on Bonnet's Considérations. There Voltaire appears well acquainted with all the problems in the beginning life sciences. In the experimental field he showed curiosity, caution, and yet, modesty. When he was told that he did not have the required skills, he publicly retracted. Voltaire was an insecure amateur and never forgot the lesson tought him by one of the most widely read naturalists of his century. Under the disguise of a meddling amateur and joker, Voltaire chose to make fun of the snail debate and, in the dissertation, of Buffon's theories of mountain-building. He seemed convinced that the spontaneous generation debate was closed and tried to convince naturalists that the theory of mountain-building by the sea was just as chimerical.

\section{Acknowledgments}

I wish to thank Professor Richard W. Burkhardt, historian of biology and chairman of the History Department, as well as Professor A. Owen Aldrige, chairman of the Department of Comparative Literature and a great scholar of Voltaire, both at the University of Illinois at 
Urbana-Champaign, Urbana Ill. 61801, U.S.A., for their most helpful review of the manuscript and constructive criticism. Without their kind encouragement I would not have been able to write this interdisciplinary paper. I would also like to express my gratitude to Dr. Charles Wirz, Curator of the Institut et Musée Voltaire at Geneva, Switzerland, for kindly making available the original versions of Les Colimaçons.

\section{Notes}

${ }^{1}$ Lazzaro Spallanzani, Prodromo di un'opera da imprimersi sopra le reproduzioni animali, Modena, 1768; see also Opere di Lazzaro Spallanzani, 6 vols., Milano, Società tipogr. de' classici italiani, 1825-1826, vol. IV, tome I, p. 10-72. It was apparently one of Spallanzani's students who first discovered regeneration in snails. See Dino Pradi, Bibliografia di Lazzaro Spallanzani, Florence, Sansoni Antiquariato, 1952, p. 43.

2 Aram Vartanian, "Trembley's Polyp, La Mettrie, and Eigtheenth-Century French Materialism," Journal of the History of Ideas, 1950, vol.11, p. 259-286.

${ }^{3}$ See Jean Rostand, Les origines de la biologie expérimentale et l'Abbé Spallanzani, Paris, Fasquelle Editeurs, 1951, p.82-84; see also Lettres à M.l'Abbé Spallanzani de Charles Bonnet, ed. Carlo Castellani, Milano, Episteme Editrice, 1971, p. 80-95, 106-107, 138-139, 271. As far as I know, the snail controversy is not entirely closed. Modern biologists prefer to work on hydra and salamanders where regenerations always occur. See Marcus Singer, "The regeneration of body parts," Scientific American, 1958, vol.199, p. 79-88; Alfred Gierer, "Hydra as a model for the development of biological form," Scientific American, 1974, vol.231, p.44-54; Peter J.Bryant, Susan V.Bryant, and Vernon French, "Biological regeneration and pattern formation," Scientific American, 1977, vol.237, p.66-81. See also Richard J.Goss, Principles of Regeneration, New York, Academic Press, 1969, where regeneration in many animals, but not in snails, is discussed.

${ }^{4}$ Les Colimaçons du Reverend Pére l'Escarbotier, Par la grace de Dieu Capucin indigne, prédicateur ordinaire \& cuisinier du grand Couvent de la ville de Clermont en Auvergne. Au Reverend Pére Elie, Carme chaussé, [Geneva] 1768, p.3. I have consulted the first original edition as well as a second edition published in 1769 at the Institut et Musée Voltaire at Geneva. Hereafter I shall refer to this work as Les Colimaçons and, citing the first edition, include the page numbers in the text. See also Euvres complètes de Voltaire, Louis Moland ed., 52 vols., Paris, Garnier Frères, 1877-1885, vol. XXVII, p. 213-226.

${ }^{5}$ The following authors have treated the spontaneous generation debate: Emile Guyénot, Les sciences de la vie aux XVII et XVIII siècles - l'idée d'évolution, Paris, Editions Albin Michel, 1957; Jacques Roger, Les sciences de la vie dans la pensée française du XVIII siècle: La génération des animaux de Descartes à l'Encyclopédie, Paris, Armand Colin, 1963; Elizabeth B.Gasking, Investigations into Generation-1651-1828, Baltimore, The Johns Hopkins Press, 1967; John Farley, The Spontaneous Generation Controversy from Descartes to Oparin, Baltimore, The Johns Hopkins Press, 1977; Shirley A. Roe, "John Turberville Needham and the Generation of Living Organism," Isis, 1983, vol. 74, p. 159-184.

${ }^{6}$ See Roe, "John Turberville Needham," p.159; Farley, Spontaneous Generation, p.21, and Charles W.Bodemer, "Regeneration and the Decline of Preformationism in Eighteenth Century Embryology," Bulletin of the History of Medicine, 1964, vol. 38, p.20-31.

'See Farley, Spontaneous Generation, p.11-12. 
${ }^{8}$ Pierre Louis Moreau de Maupertuis, Vénus Physique (1745) in Euvres, 4 vols., Hildesheim, New York, Georg Olms Verlag, 1965-1974, vol.2, p.86-89; Buffon, Histoire naturelle, générale et particulière, vol.II, Paris, 1749; Needham, "A Summary of some late Observations upon the Generation, Composition, and Decomposition of Animal and Vegetable Substances," Philosophical Transactions of the Royal Society of London, 1748, vol.45, p. 615-666.

${ }^{9}$ Farley, Spontaneous Generation, p. 22.

10 Spallanzani, «Memoria seconda ed ultima. Sopra la riproduzione della Testa nelle Lumache terrestri,» Memorie di Matematica e Fisica della Società Italiana, 1784, Verona, vol.2, pt.2, p.506-602, on p.569. Bonnet, Euvres d'histoire naturelle et de philosophie, 8 vols., Neuchâtel, Imprimerie Samuel Fauche, 1779-1783, vol. V, pt. I, p. 338.

${ }^{11}$ Bonnet, Traité d'insectologie, ou Observations sur les Pucerons, Paris, Durand, 1745, pt.I, preface and pt. II, p.94-96. The controversy about the divisibility of the animal soul and Voltaire's criticism of Bonnet has been treated by Rostand, Les origines, p. 89-90, and by Jacques Marx, "Charles Bonnet contre les Lumières - 1738-1850," Studies on Voltaire and the Eighteenth Century, 1976, vols, 156 and 157, in 157, p. 519-524.

${ }^{12}$ Bonnet, Euvres, vol.III, preface p.IX; Spallanzani, Saggio di osservazioni microscopiche concernenti il sistema della generazione de' Signori di Needham e Buffon, Modena, 1765.

${ }^{13}$ Bonnet, Euvres, vol. III, pt. II, chapt. I, p. 238-239.

${ }^{14}$ Bonnet to Spallanzani, 27 December 1765, in Lettres, p. 9-10.

15 Spallanzani to Bonnet, 21 September 1766, in Lazzaro Spallanzani Epistolario, ed. Benedetto Biagi, 5 vols., Florence, Sansoni Antiquariato, 1958-1964, vol. I, p. 115.

16 Bonnet to Spallanzani, 9 October 1766, in Lettres, p. 42-43.

${ }_{17}$ Bonnet, CEuvres, vol. III, 2nd pt., p. 271-272, and Bonnet to Spallanzani, 9 October 1766, in Lettres, p. 37-38.

18 Bonnet to Spallanzani, 29 April 1767, in Lettres, p. 51.

${ }^{19}$ Bonnet, Euvres, vol. III, pt. I, p. 55, 143; pt. II, p. 238-239, 479.

20 Spallanzani, Prodromo, p. 12.

${ }^{21}$ Spallanzani, Prodromo, p. 29.

22 Spallanzani, Prodromo, p. 34.

23 Spallanzani, Prodromo, p. 51.

24 Spallanzani to Bonnet, 6 June 1767, in Epistolario, vol. I, p. 138.

${ }^{25}$ Bonnet to Spallanzani, 26 August 1769 and 23 October 1779, in Lettres, p. 108, 386-387.

${ }^{26}$ Bonnet to Spallanzani, 26 July 1775 and 27 January 1776, in Lettres, p. 292, 302.

${ }^{27}$ Bonnet, "Expériences sur la régénération de la tête du limaçon terrestre," Observations sur la Physique, sur l'Histoire Naturelle et sur les Arts, Paris, 1777, vol.10, p.165-179, see p. 165. See also Euvres, vol.V pt.I.246. Bonnet published two more articles in Observations: «Premier mémoire sur la reproduction des membres de la Salamandre aquatique,» Paris, 1777, vol.10, p.358-405; «Second mémoire sur la reproduction des membres de la salamandre aquatique,» Paris, 1779, vol.13, p.1-18. These three articles were reprinted in Bonnet's Euvres, vol.V, pt.I, p.246-339, including a second article on snails never published before: «Second mémoire sur la régénération de la tête du limaçon,» p. 267-283. Hereafter I shall refer to Euvres unless there are important differences between Euvres and Observations. The four memoirs mentioned above were translated in Tracts on the Natural History of Animals and Vegetables, 2 vols., second edition, Edinburgh, 1803, vol.II, 
p. 317-417. I have freely borrowed from this translation instead of offering mine unless the French original varied from the English translation.

28 Bonnet, Euvres, vol. V, pt. I, p. 309-310.

29 Bonnet, Euvres, vol. V, pt. I, p.316.

30 Bonnet, Euvres, vol. V, pt. I, p.316-331.

${ }^{31}$ Bonnet, Euvres, vol. V, pt. I, p. 331-332.

32 Bonnet, CEuvres, vol. V, pt. I, p. 334, 335, 337.

${ }^{33}$ Bonnet, Euvres, vol. V, pt. I, p. 333.

34 Bonnet, Euvres, vol.V.pt.I, p.335. This footnote does not exist in «Second mémoire,» Observations, 1779, vol.13, p. 1-18.

35 Spallanzani, «Risultati di esperienze sopra la Riproduzione della Testa nelle Lumache terrestri,» Memorie di Matematica e Fisica della Società Italiana, 1782, Verona, vol.I. p. 581-612. In the same periodical appeared «Memoria seconda ed ultima» Sopra la riproduzione della Testa nelle Lumache terrestri,» 1784, Verona, vol. II, pt. II, p.506-602. These two memoirs were translated in part in Tracts, vol. II, p. 219-316; I shall also use this translation if alike in every way to the French original.

36 Spallanzani, «Risultati,» p. 588.

37 Spallanzani, «Risultati,» p. 608.

38 Spallanzani, «Risultati,» p. 587, 597-598, 600, 606.

39 Bonnet to Spallanzani, 15 August 1778, in Lettres, p. 368-369.

40 Spallanzani, «Risultati,» p. 599-601.

41 Spallanzani, «Risultati,» p. 604-608.

42 Spallanzani, «Memoria seconda», p. 569. Goss states that in the broadest sense "regeneration is synonymous with reproduction, especially vegetative reproduction" (Principles, p.2). Singer, however, believes that there is a great difference between regeneration and embryonic development because the embryo grows apart from the adult or screened from its tissues while cells of regenrating tissues arise from the cells of adult tissues (Regeneration of body parts, p. 82).

${ }^{43}$ Charles W.Bodemer, "Regeneration," p. 20-31. See p. 30 and 31.

${ }^{44}$ According to Farley, Spontaneous Generation, p.31; he also mentions that materialistic views of the French philosphes such as Diderot merged with the ideas of German Naturphilosophen (p.28).

45 Edmond Bordage, «Deux précurseurs en biologie - Voltaire et Bernardin de Saint-Pierre,» Biologica, Revue Scientifique du Médecin, May 1912, Paris, p. 135-143.

46 Marcel Abeloos, «Sur la régénération de la tête des Mollusques Gastéropodes,» Comptes Rendus hebdomadaires des Séances de l'Academie des Sciences, Paris, June 1, 1942, vol.214, p. 883-884. I have not found any more recent explanation.

47 Rostand, Les origines, p. 85-93.

${ }^{48}$ Les Singularités de la nature par un Académicien de Londres, de Boulogne, de Berlin, \&c., Basle [Geneva], 1768, See also Euvres, Moland ed., vol. XXVII, p. 125-191.

49 Voltaire owned Jacques-Christophe Valmont de Bomare, Dictionnaire raisonné universel d'histoire naturelle, 9 vols., Lausanne, 1776. (The dictionnaire was first published in 1764). See M.P.Alekseev and T.N.Kopreeva, Voltaire's Library: Catalogue of Books, MoscowLeningrad, Academy of Sciences of the U.S.S. R., 1961. Valmont de Bomare distinguished "limaces" without shells from «limaçons,» «escargots,» and «colimaçons» all with shells. He 
described decapitation of snails and not of slugs (vol. V, p. 134-139). Voltaire's letters to d'Argental, du Deffant, and de Chabanon were labeled by Besterman as D 15157, D 15163, and D 15283, respectively, in The Complete Works of Voltaire, Theodore Besterman ed., Geneva, Banbury, Oxfordshire, and Toronto (1968-). Voltaire's Dictionnaire Philosophique is included in Euvres, Moland ed., vol. XVII-XX; his Rétraction in Euvres, Moland ed., vol. XX, p.621-622; his letters to Spallanzani are labeled D 20133 and D 20158.

${ }^{50}$ See Marguerite Carozzi, "Voltaire's Attitude toward Geology," Archives des Sciences, Geneva, 1983, vol.36, p.1-145, for a discussion of the controversies on fossils and mountain-building in the eighteenth century and of Voltaire's various works which include geological observations. These were based on independent studies in the neighborhood of Ferney and point to his accuracy and empirical methods. The Saggio was translated by Voltaire in 1748 under the title Dissertation sur les changements arrivés dans notre globe et sur les pétrifications qu'on prétend en être encore les témoignages in Euvres, Moland ed., vol.XXIII, p.219-230. See also in the same edition La défense de mon oncle, vol. XXVI, p. 367-433 and L'Homme aux quarante écus, vol. XXI, p. 305-368.

51 Articles extraits de la Gazette Littéraire de l'Europe, 4 avril 1764, Euvres, Moland ed., vol. XXV, p. 153-156.

52 Marx, «Charles Bonnet,» pt. II. p. 526-529.

${ }^{53}$ Bonnet's work La Palingénésie Philosophique, published in 1769, was criticized by Voltaire in Dieu et les Hommes, Euvres, Moland ed., XXVIII, p.218-219; Fragments historiques sur l'Inde et sur le général Lally, Euvres, Moland ed., vol.XXIX, p.178, and in a letter to Spallanzani on May 20, 1776, Besterman D 20133.

${ }^{54}$ Voltaire, CEuvres, Moland ed., vol. XXV, p. 155.

${ }_{55}$ Rachel Horwitz Westbrook, John Turberville Needham and his Impact on the French Enlightenment, unpublished Ph. D. Thesis, Columbia University, New York, 1972, p.138; Roe, "John Turberville Needham," p. 90.

56 On Voltaire's quarrel with Buffon, see Carozzi, "Voltaire's Attitude," p.47-128. I have not drawn any conclusion in my dissertation although it is quite evident that Voltaire referred to Buffon whenever he criticized geological theories after Buffon's Histoire naturelle.

57 Rostand, Les origines, p. 90.

58 According to a handwritten note in the original edition of 1769 in Les Colimaçons at the Institut et Musée Voltaire, Rétraction was published in Question sur l'Encyclopédie in the «édition encadrée» of 1775 , p. 517.

59 Valmont de Bomare, Dictionnaire, vol. V, p. 145-146.

60 Voltaire to Spallanzani, May 20, 1776, Besterman D 20133; Spallanzani to Voltaire, May 31. 1776, Besterman D 21048; Voltaire to Spallanzani, 6 June 1776, Besterman D 20158.

61 See Carozzi, "Voltaire's Attitude," p. 89-91.

${ }^{62}$ Voltaire, Les Singularités, Moland ed., p. 125-126.

\section{Summary}

Charles Bonnet and Lazzaro Spallanzani were both searching for preexisting germs in regenerating animals in order to provide visible proof for the theory of preexistence. Snail heads, however, did not regenerate with constancy, no organic part or whole seemed to pop out 
from preexisting germs. On the contrary, some parts developed almost at random, others showed monstrous deformities: it was a blow to their theory of preexistence. Although Bonnet tried to save the theory, admitting germs where there were none, the snail debate probably marked the end of the preformation versus epigenesis controversy in the eighteenth century.

While modern biologist still enjoy Voltaire's jokes on the soul's residence at the behind of a decapitated snail, Les Colimaçons represent more than just a satire on the snail debate. In the dissertation by a physician from St. Flour Voltaire refutes Buffon's theory of mountain-building by the sea. Being convinced that the spontaneous generation debate was closed after Spallanzani's Saggio, Voltaire continued his fight against other system-markers. His comments on embryology and regeneration show that he was well acquainted with the problems in the beginning life sciences. In his own experiments he showed curiosity, caution, and modesty. All his statemets are, however, couched in ambiguous terms in order to protect himself from his contemporaries. He did not wish to become a laughingstock again.

\section{Zusammenfassung}

Charles Bonnet und Lazzaro Spallanzani suchten bei regenerierenden Tieren nach ursprünglich existierenden Keimen, um die Theorie der Präexistenz zu beweisen. Die Köpfe der Schnecken wurden aber nicht regelmäßig regeneriert; kein ganzes organisches Wesen entwickelte sich aus vorbestandenen Keimen. Im Gegenteil: einige Teile entwickelten sich beinahe ziellos, und andere erzeugten unförmige Mißbildungen. Das war ein Schlag für die Theorie der Präexistenz. Bonnet versuchte zwar die Theorie zu retten mit der Anerkennung von Keimen, welche in Wirklichkeit nicht vorhanden waren. Jedoch der Streit um Präformation oder Epigenesis im 18. Jahrhundert kam damit zu einem Ende.

Voltaires Witze über den Sitz der Seele am Gesäß geköpfter Schnecken werden immer noch belächelt, aber seine unter einem Pseudonym publizierte Arbeit «Les Colimaçons» ist mehr als eine Satire über die Schnecken-Debatte. Er war sicher, daß die Theorie der Spontanerzeugung nach Spallanzanis Saggio erledigt war, und er führte einen allgemeinen Kampf gegen die Systematiker. Seine Stellungnahmen zu Problemen der Embryologie und Regeneration zeigen, da $\beta$ er über gute Kenntnisse der damaligen Anfänge biologischer Wissenschaften verfügte. Um sich gegen seine Zeitgenossen zu schützen - besonders gegen Buffon - und sich nicht wieder lächerlich zu machen, tarnte er sich durch die Masken der Pseudonyme.

Dr. Marguerite Carozzi

Department of Geology

N. H. B. 245

University of Illinois at Urbana-Champaign

Urbana, Ill. 61801, U.S. A. 